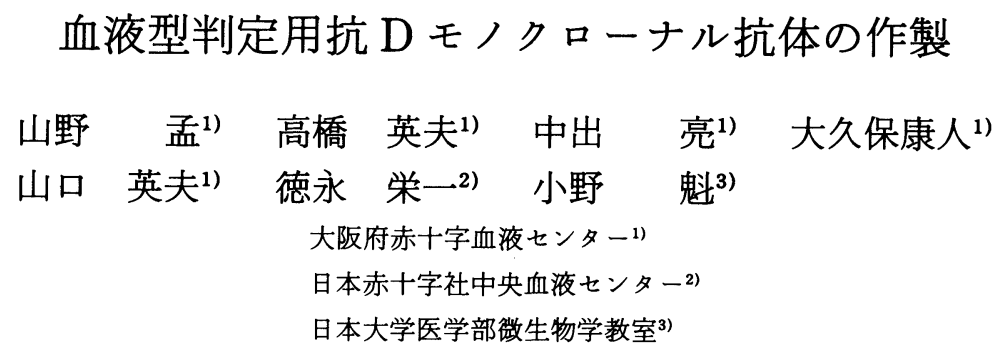

(平成元年 6 月 1 日受付)

\title{
PRODUCTION OF MONOCLONAL ANTI-D FOR USE IN TYPING BLOOD GROUPS
}

\author{
Hajime Yamano, Hideo Takahashi, Toru Nakade, Yasuto Okubo and Hideo Yamaguchi \\ Osaka Red Cross Blood Center \\ Eiichi Tokunaga \\ Japanese Red Cross Central Blood Center \\ Yasushi Ono \\ Department of Microbiology, Nihon University School of Medicine
}

A monoclonal anti-D typing reagent was prepared in following ways.

The monoclonal anti-D was generated in hybridoma cell line (DBF-11) established by the use of "EBV-Hybridoma Technique", in which an Epstein-Barr Virus (EBV)-transformed monoclonal anti-D (IgG1, $\kappa$ chain) producing human B-cell line (B2-1) was fused with non-immunoglobulin producing JMS-3 cell.

Mass culture of the cell line (DBF-11) was continued for the period of over 131 days, by using the continuous cell culturing apparatus (Bio-Pro) provided with "vitafiber".

Weight of the monoclonal anti-D obtained from 8.17 liters of the cultured supernatant fluid was $5.1 \mathrm{~g}$ expressed in terms of human IgG.

After being roughly purified with "hollowfiber", the IgG content was $4.4 \mathrm{~g}$.

The Fc portion of the roughly purified IgG $(40 \mu \mathrm{g} / \mathrm{ml})$ was bound with mouse anti-human IgG (Fc monospecific antibody: $32 \mu \mathrm{g} / \mathrm{ml}$ ) so that the monoclonal anti-D was rendered suitable for a blood typing reagent.

\section{はじめに}

Rho(D) 抗原に特異的な抗 D モノクローナル抗 体の作製については, 1980年に Koskimies ${ }^{1)}$, 同年 Boylston ら²)が抗 D産生 B リンパ球に EBV (Epstein-Barr virus) をトランスフォームするこ とによって抗 Dモノクローナル抗体産生株を樹 立している。

その後, 1984年に Bron ら ${ }^{3)}$ は, 抗 D 産生 EBV トランスフォーム細胞とヒトーマウスヘテロミエ ローマ細胞の融合を報告し，1986年に Lowe ら は, 抗 D産生 EBVトランスフォーム細胞と human lymphoblastoid cell line との融合によっ てそれぞれ安定な抗 Dモノクローナル抗体産生 株を樹立している。

我々は，1983年に日本大学医学部微生物学教室 で開発された抗 Dモノクローナル抗体産生株 B2-1 細胞 ${ }^{5)}$ と JMS-3 細胞の融合によって安定な抗 $\mathrm{D}$ モノクローナル抗体産生株を分離し, さらに 3 回のクローニングを行い抗 Dモノクローナル抗 体産生株 DBF-11を樹立した。

この細胞の大量培養は, 連続細胞培養装置 “Bio-Pro”（アミコン製ヴィタファイバーVを内 
装したグレースジャパン製）を使用した。

培養上清を精製した後, 抗 Dモノクローナル抗 体 IgG の Fc 部を架橋し，臨床検査に使用可能な 抗 D 血液型判定用モノクローナル抗体〔商品名： 抗 D「日赤」「の開発に成功した。

\section{I. 材 料}

1. 細胞

1）B2-1（日本大学医学部小野教授から分与さ れた抗 D 産生 EBVトランスフォーム細胞）

2) 親細胞 JMS-3

〔HGPRT (hypoxanthine guanine phosphoribosyl transferase) 欠損株, 日本大学医学部小野 教授から分与]

2. 培地执よび試薬

1) RPMI1640培地

組成

RPMI1640培地（日水製薬）

$1.04 \mathrm{~g}$

L-glutamin (片山化学)

リラシリン注射用（武田製薬） $30 \mathrm{mg}$ $5 \mathrm{mg}$

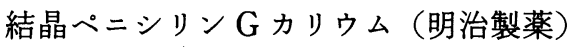

$5 \mathrm{mg}$

硫酸ストレプトマイシン（明治製薬） $10 \mathrm{mg}$ 炭酸水素ナトリウム（片山化学） 160mg 純水 $100 \mathrm{~m} l$

2) FBS (Fetal bovine serum) (Hyclone 製)

3）HOTD 選択培地（HAT・ Ouabain 培地） 組成

RPMI1640培地 1 リットルに最終濃度として次 のものを添加する.

$\begin{array}{ll}\text { hypoxanthine (Sigma) } & 1 \times 10^{-4} \mathrm{~mol} \\ \text { aminopterin (Sigma) } & 1 \times 10^{-5} \mathrm{~mol} \\ \text { thymidine (Sigma) } & 4 \times 10^{-5} \mathrm{~mol} \\ 2^{\prime} \text {-deoxy cytidine (Sigma) } & 1 \times 10^{-6} \mathrm{~mol} \\ \text { ouabain (Sigma) } & 5 \times 10^{-7} \mathrm{~mol}\end{array}$

4) HAT 培地

組成

RPMI1640培地 1 リットルに最終濃度として次 のものを添加する.

hypoxanthine (Sigma)

$1 \times 10^{-4} \mathrm{~mol}$

aminopterin (Sigma)

$1 \times 10^{-5} \mathrm{~mol}$

thymidine (Sigma) $2^{\prime}$-deoxy cytidine (Sigma) $\quad 1 \times 10^{-6} \mathrm{~mol}$

5) HT 培地

組成

RPMI1640培地 1 リットルに最終濃度として次 のものを添加する.

hypoxanthine (Sigma) $1 \times 10^{-4} \mathrm{~mol}$

thymidine (Sigma) $4 \times 10^{-5} \mathrm{~mol}$

$2^{\prime}$-deoxy cytidine (Sigma) $1 \times 10^{-6} \mathrm{~mol}$

6) $50 \%$ PEG 液 : polyetylene glycol (M.W. : $1,500, \mathrm{BDH}$ 製)

$1 \mathrm{~g}$ を試験管に入れオートクレーブで溶解後 40〜 50 ${ }^{\circ} \mathrm{C}$ に冷却し, $1 \mathrm{~m} l$ の RPMI1640培地を加兄 よく混和する。

7) seaplaque agarose (FMC 製)

8）ラナプレート IgG-L（日本化薬製）

9) IgG subclass specific antisera (M1174 Janssen)

10） $0.5 \%$ フィシン処理 Rho (D) 陽性血球液： フィシン粉末 $1 \mathrm{~g}$ をPBS (1/10M, pH：7.3) 100 $\mathrm{m} l$ に溶解し，室温で15分間擋汼後 $1,000 \mathrm{G} 5$ 分間 遠心後, 上清 $1 \mathrm{~m} l$ を PBS で10倍に希釈後, 洗浄赤 血球を $2 \mathrm{~m} l$ 加光 $37^{\circ} \mathrm{C} 15$ 分間インキュベート後, 生 理食塩液で 3 回洗浄し， $0.5 \mathrm{~V} / \mathrm{V} \%$ 血球浮遊液と する.

11） $0.5 \%$ ブロメリン液：0.5gのブロメリン粉 末(Merck 製)を $0.1 \% \mathrm{NaN}_{3}$ を含む $\mathrm{PBS}(1 / 15 \mathrm{M}$, $\mathrm{pH}: 5.5) 100 \mathrm{~m} l$ に溶解する。

12）ウシアルブミン末 (Sigma 製)

13） $22 \%$ ウンルブミン液（オーソ製）

\section{II. 方 法}

1. B2-1細胞と JMS-3細胞の融合

B2-1細胞 $6.8 \mathrm{~m} l\left(1 \times 10^{6}\right.$ 個 $\left./ \mathrm{m} l\right)$ と JMS-3 細胞 $6.8 \mathrm{~m} l\left(1 \times 10^{6}\right.$ 個 $\left./ \mathrm{m} l\right)$ をそれぞれ RPMI1640培 地で洗浄後モルトン管へ移し, 混合後1,000r.p.m. 5 分間遠心し上清を除去する，次に $50 \%$ PEG 液1 $\mathrm{m} l$ をゆっくり30秒間で加え, さらに30秒間混合 し, RPMI1640培地を $1 \mathrm{~m} l, 10 \mathrm{~m} l$ の順に加え 1,000 r.p.m. 5 分間遠心後上清を除去 L $20 \% \mathrm{FBS}$ 加 RPMI1640培地 $6.8 \mathrm{~m} l$ で細胞を分散し，マイクロ プレート（住友ベークライト MS-3096F）に1well 当り, 親細胞数から換算して $5 \times 10^{4}$ 個 $/ 100 \mu l$, 
$1 \times 10^{5}$ 個 $/ 100 \mu l$ の 2 種類に調製して分注し, $37^{\circ} \mathrm{C}, 5 \% \mathrm{CO}_{2}$ で培養後, 翌日 HOTD 培地を 100 $\mu l$ ずつ各 well に加光, 以後 4 日毎に HOTD 培地 で培養上清を半量交換する。 3 週間経過後 4 日毎 にHAT 培地で培養上清を半量交換， 6 週間後 HT 培地で培養上清を半量交換し約 2 週間後培養 液を20\%FBS 加 RPMI1640培地に交換後，4 日毎 に培地を交換し培養を継続する。

クローンの形成が認められた well の上清を Rho (D) 陽性血球を用いて，ブロメリン法によっ て抗 Dの有無をスクリーニングし，抗 D 産生ク ローンを検索する.

2. 軟寒天法によるクローニング

支持層は, $0.5 \mathrm{~g}$ のアガロースに $40 \mathrm{~m} l$ の純水を 加劣オートクレーブで隇菌後, $50 \sim 55^{\circ} \mathrm{C}$ に冷却し RPMI1640培地（2 倍濃度） $40 \mathrm{~m} l$, FBS $20 \mathrm{~m} l$ を 加光混合し, 直径 $6 \mathrm{~cm}$ のシャーレ (LUX5220) に $4 \mathrm{~m} l$ ずつ分注し $5{ }^{\circ} \mathrm{C}$ でゲル化する.

接種層は, $0.2475 \mathrm{~g}$ のアガロースに純水 $30 \mathrm{~m} l$ を 加光隇菌後50 55 ${ }^{\circ} \mathrm{C}$ に冷却し, RPMI1640培地 ( 2 倍濃度) $30 \mathrm{~m} l$ に FBS $15 \mathrm{~m} l$ を加光混合した後, 3 等分しそれぞれに抗 D 産生融合細胞を $1 \times 10^{2}$ 個 $/ 3 \mathrm{~m} l, 2 \times 10^{2}$ 個 $/ 3 \mathrm{~m} l, 5 \times 10^{2}$ 個 $/ 3 \mathrm{~m} l$ に浮遊 し，支持層上に $3 \mathrm{~m} l$ を重層する. $37^{\circ} \mathrm{C} ， 5 \% \mathrm{CO}_{2}$ の 条件下で $3 \sim 4$ 週間培養後にコロニーの形成が認
められ，このコロニ-1個ずつをマイクロプレー 卜（住友ベークライト MS3096F）に移し，増殖さ せ抗 Dモノクローナル抗体産生単クローンを樹 立した。

\section{3. 大量培養}

単クローン化した抗 Dモノクローナル抗体産 生融合細胞(DBF-11)を10\%FBS 加 RPMI1640培 地に $2 \times 10^{5}$ 個 $/ \mathrm{m} l$ 浮遊し, 3 日間カルチャーボト ルで培養した細胞 $2 \times 10^{8}$ 個をBio-Pro（図 1）で 長期間培養を行った。

Bio-Proは，ヴィタファイバーV（分画分子量 30,000, アミコン製)を内装している。ヴィタファ イバーV $\mathrm{V}$ は中空ファイバーの数千本の束からな り，管腔は培地が還流し，ファイバー外腔は高密 度の細胞を増殖させる機構を有している，本体装 置は, 加圧方式によって液体の流動を制御し, $\mathrm{pH}$, $\mathrm{DO}$ 值 (溶存酸素) を $\mathrm{CO}_{2}, \mathrm{O}_{2}, \mathrm{~N}_{2}$ の各々のガス によってコントロールし，細胞の増殖を最適条件 下に維持することができる。すず,本体コントロー ラのキーボードで培養条件，1）庫内温度： $37^{\circ} \mathrm{C}$,

2) 培地の $\mathrm{pH}: 6.80 \sim 7.30,3) \mathrm{DO}: 3.0 \sim 4.0$, 4）培地の移動方向(左巴右)，5）培地の擋挥子の 回転数 : 200r.p.m., 6) 培地の流速 : $250 \sim 350 \mathrm{ml} /$ 分を入力後, ファイバーを装着し, RPMI1640培地 2.8 リットルを 24 時間循環させ，翌日10\%FBS 加

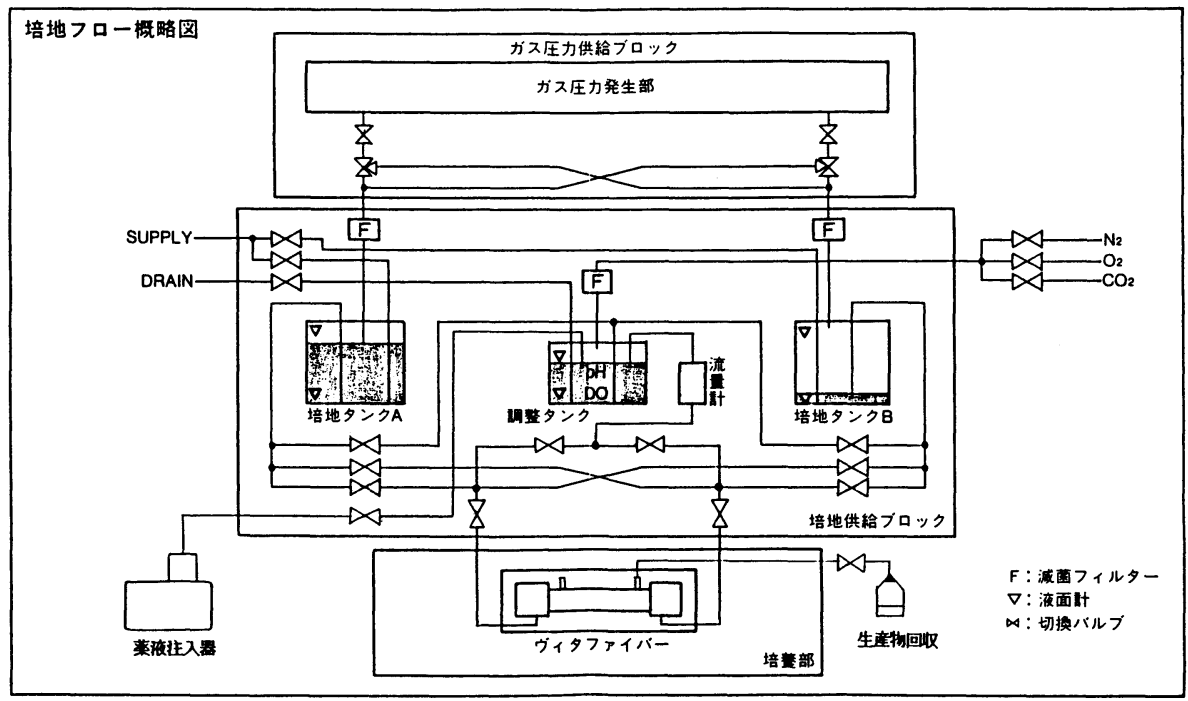

図 1 連続細胞培養装置 Bio-Pro 
RPMI1640培地量2.8リットルに交換後, 循環さ せ，DBF-11細胞を $2 \times 10^{8}$ 個 $/ 10 \mathrm{~m} l$ 個ファイバー に接種する。培地の劣化の判断は, グルコース量 が約 $20 \mathrm{mg} / \mathrm{d} l$ 以下に低下すれば培地の交換を行 う（1回の必要培地量は2.8リットル）。毎日培地 を交換しなければならない場合は，時間設定によ る自動交換を行う。培地の FBS 添加量は, 培養初 期から55日目亲で $10 \%$, 抗 D抗体価が $8 \times 10^{4}$ 倍 に上昇した 56 日目から $5 \%$ に減量, 70 日目以後は この細胞の増殖限界である $3 \%$ をでに減量して 131日目まで培養し, 以後培養系に細菌のコンタミ ネーションが生じたため培養を中止した。

産生物は, ファイバーの外腔採取口から注射器 で抗体価上昇後每日平均 $80 \mathrm{~m} l$ を採取した。

\section{4. 産生物の精製および性状}

産生物の精製はホローファイバーによる限外滤 過によって濃縮精製した。

免疫グロブリンについては, 免疫電気泳動法 [へ ロナール緩衝液 $(\mathrm{pH} 8.6$, イオン強度0.05), 寒天 (片山化学製) $1 \mathrm{~W} / \mathrm{V} \%$ によって判定した。

IgG サブクラスについては, 抗 D モノクローナ ル抗体感作血球〔精製抗 Dモノクローナル抗体原 液の 1,000 倍希釈液 1 容に Rho(D) 陽性血球（ $3 \%$ 生理食塩液浮遊液) 1 容を加光 $37^{\circ} \mathrm{C} 30$ 分間加温後, 生理食塩液で 3 回洗浄した血球液」 1 滴に IgG subclass specific antisera (M1174 Janssen 製) の各抗体 1 滴を加え抗グロブリン試験によって判 定した。

ヒト IgG 量は，ラナプレート IgG-L（日本化薬 製）を用いて定量した。

凝集価は, 精製抗 Dモノクローナル抗体を生理 食塩液で100倍希釈した後, 2 倍連続希釈し Rho (D) 陽性血球を用いて, ブロメリン法, 抗グロブ リン試験によって力価を求めた。

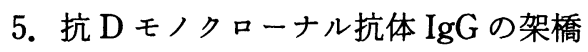

精製抗 Dモノクローナル抗体（ヒト IgG）をリ ン酸緩衝食塩液（PBS：0.013M, pH 7.0）を用 いて, $100 \mu \mathrm{g} / \mathrm{m} l, 80 \mu \mathrm{g} / \mathrm{m} l, 60 \mu \mathrm{g} / \mathrm{ml}, 40 \mu \mathrm{g} / \mathrm{m} l$, $20 \mu \mathrm{g} / \mathrm{m} l$ の希釈系列を作製後, 各々の希釈液を $100 \mathrm{~m} l$ ずつ 4 本の容器に分注し, 抗ヒト IgG Fc 特異マウスモノクローナル抗体液 $(3.2 \mathrm{mg} / \mathrm{ml})$ の
$1.0 \mathrm{~m} l, 0.5 \mathrm{~m} l, 0.25 \mathrm{~m} l, 0.125 \mathrm{~m} l$ の 3 段階液を それぞれに加え混合した後, $37^{\circ} \mathrm{C} て ゙ 1$ 時間反応さ せ，ヒト IgGの 2 分子間の Fc 部分を架橋した 20 種類を作製し，それぞれにウシアルブミン粉末を $0.5 \mathrm{~W} / \mathrm{V} \%$ になるらに添加して調製した。この 調製液について, 食塩液凝集試験, アルブミン液 凝集試験, 凝集力試験（凝集開始時間）を実施し て凝集価および感度の高い混合比を決定した。

\section{III. 成 績}

\section{B2-1細胞と JMS-3細胞の融合}

融合細胞を親細胞（JMS-3）数から換算し $1 \times$ $10^{5}$ 個/well の場合のクローンの形成は, 30well 中 23well (76.7\%) に認め，そのすべてに抗 D 活性 を認めた。 $5 \times 10^{4}$ 個/well の場合は, 36well 中21 well(58.3\%)にクローンを形成し，そのすべてに 抗 D 活性を認めた（表 1 ）。

このうち抗 D 活性が高く, 細胞増殖の良い well （植え込及細胞数 $1 \times 10^{5}$ 個/well の B-7, B-11, D7, D-11の 4well および植え込及細胞数 $5 \times 10^{4}$ 個/ well の B-8, D-5の2well) の計 6 細胞 (6well) 株 を分離した。

2.クローニング

1）初回クローニング（表 2）

6 細胞の各々のコロニー形成は, B-7が20 シャーレ中47個 (0.67\%)，B-11が21シャーレ中 203 個 (3.03\%)，D-7が20シャーレ中 178 個 (3.63\%), D-11が30シャーレ中378個 (4.73\%), B- 8 が 30 シャーレ中 490 個 (6.13\%)，D-5が 20 シャーレ中481個 (8.02\%) であった。これらのコ ロニ一中増殖の良いB-7の35個 (高橋ら ${ }^{6}$, 星野ら の報告), B-11の87個, D-7の120個, D-11の98個, B-8の97個，D-5の100個をそれぞれマイクロプ

表 1 B2- 1 細胞と JMS- 3 細胞の融合による抗 D 陽性株

\begin{tabular}{c|c|c}
\hline Cells(JMS-3)/Well & $\begin{array}{c}\text { Colonies/Well } \\
\text { (\%) }\end{array}$ & $\begin{array}{c}\text { Frequencies of } \\
\text { Positive Clone } \\
\text { with Anti-D(\%) }\end{array}$ \\
\hline $1 \times 10^{5}$ & $23 / 30(76.7)$ & $23 / 23(100)$ \\
$5 \times 10^{4}$ & $21 / 36(58.3)$ & $21 / 21(100)$ \\
\hline
\end{tabular}

*抗 D産生初代細胞 6 株の樹立 : B-7, B-11, D-7, D-11, B $-8, \mathrm{D}-5$ 
表 2 初代融合細胞の軟寒天法によるクローニング

\begin{tabular}{|c|c|c|c|c|}
\hline $\begin{array}{l}\text { Clone } \\
\text { Number }\end{array}$ & Cells/Plate & Colonies/Plate & $\begin{array}{l}\text { Frequencies of Cell Growth } \\
\text { in Microtiter Plate(\%) }\end{array}$ & $\begin{array}{l}\text { Frequencies of } \\
\text { Positive Clone } \\
\text { with Anti-D }(\%)\end{array}$ \\
\hline B- 7 & $\begin{array}{l}5 \times 10^{2} \\
2 \times 10^{2}\end{array}$ & $\begin{array}{r}45 / 10 \\
2 / 10\end{array}$ & $27 / 35(77.1)$ & $25 / 27(92.6)$ \\
\hline B-11 & $\begin{array}{l}5 \times 10^{2} \\
2 \times 10^{2} \\
1 \times 10^{2}\end{array}$ & $\begin{array}{r}110 / 10 \\
45 / 6 \\
48 / 5\end{array}$ & $85 / 87(97.7)$ & $29 / 85(34.1)$ \\
\hline D- 7 & $\begin{array}{l}5 \times 10^{2} \\
2 \times 10^{2} \\
1 \times 10^{2}\end{array}$ & $\begin{array}{r}103 / 6 \\
36 / 5 \\
37 / 9\end{array}$ & $115 / 120(95.8)$ & $57 / 115(49.6)$ \\
\hline D-11 & $\begin{array}{l}5 / 10^{2} \\
2 \times 10^{2} \\
1 \times 10^{2}\end{array}$ & $\begin{array}{r}233 / 10 \\
96 / 10 \\
49 / 10\end{array}$ & $98 / 98(100)$ & $88 / 98 \quad(89.8)$ \\
\hline B- 8 & $\begin{array}{l}5 \times 10^{2} \\
2 \times 10^{2} \\
1 \times 10^{2}\end{array}$ & $\begin{array}{r}318 / 10 \\
135 / 10 \\
37 / 10\end{array}$ & $97 / 97(100)$ & $83 / 97(85.6)$ \\
\hline$D-5$ & $\begin{array}{l}5 \times 10^{2} \\
1 \times 10^{2}\end{array}$ & $\begin{array}{r}443 / 10 \\
38 / 10\end{array}$ & $99 / 100(99.0)$ & ${ }^{*} 65 / 99(65.7)$ \\
\hline Total & & & $521 / 537(97.0)$ & $347 / 521(66.6)$ \\
\hline
\end{tabular}

*抗 D産生細胞65例中 B-9細胞株を樹立

レートに移し培養後,クローンを形成した well はそれぞれ27/35well (77.1\%)，85/87well (99.7\%), 115/120well (95.8\%), 98/98well (100\%), 97/97well (100\%), 99/100well (99\%) 総数 537 well 中 521 well (97\%) であり，このうち 抗 D 活性を認めた well は，それぞれ25/27well (92.6\%), 29/85well (34.1\%), 57/115well $(49.6 \%), 88 / 98$ well $(89.8 \%), 83 / 97$ well (85.6\%), 65/99well (65.7\%) 総数521well 中347 well (66.6\%) であった.

D-5細胞のクローニングによって, 単クローン 化した65クローンのうち抗 D 活性 (1,280倍)の高 い1クローン（B-9細胞株）を分離した。

2）B-9細胞株のクローニング

表 3 に示すごとく，抗 D 活性を認めた well は, 150well 中76well (50.7\%) これらの中から抗 D 抗 体価の高い 6 細胞株 (B-11, C-11, E-8, B-5, B8，E-2）を分離した。

3）B-11細胞株のクローニング

表 4 に示すごとく，抗 D 活性を認めた well は, 120well 中106well (88.3\%) このらち 3 細胞株 (DBC-5, DBC-11，DBF-11）を分離し，抗 D 活性 が高い（1,280倍）DBF-11細胞株樹立しこの細胞 を大量に培養した。
表 $3 \quad$ B-9細胞株のクローニング

\begin{tabular}{c|c|c|c}
\hline $\begin{array}{c}\text { Clone } \\
\text { Number }\end{array}$ & Cells/Plate & Colonies/Plate & $\begin{array}{c}\text { Frequncies of } \\
\text { Positive Clone } \\
\text { with Anti-D(\%) }\end{array}$ \\
\hline B-9 & $1 \times 10^{3}$ & $206 / 5$ & $18 / 36(60.0 \%)$ \\
& $5 \times 10^{2}$ & $380 / 10$ & $24 / 54(44.4 \%)$ \\
$2.5 \times 10^{2}$ & $202 / 10$ & $34 / 60(56.7 \%)$ \\
\hline Total & & & $76 / 150(50.7 \%)$ \\
\hline
\end{tabular}

*抗 D産生細胞樹立 6 株：B-11, C-11, E-8, B-5, B-8, E-2

表 $4 \quad$ B-11細胞株のクローニング

\begin{tabular}{c|c|c|c}
\hline $\begin{array}{c}\text { Clone } \\
\text { Number }\end{array}$ & Cells/Plate & Colonies/Plate & $\begin{array}{c}\text { Frequencies of } \\
\text { Positive Clone } \\
\text { with Anti-D(\%) }\end{array}$ \\
\hline B-11 & $5 \times 10^{3}$ & $588 / 14$ & $48 / 60(80.0 \%)$ \\
$2.5 \times 10^{2}$ & $174 / 10$ & $58 / 60(96.7 \%)$ \\
\hline Total & & & $106 / 120(88.3 \%)$ \\
\hline
\end{tabular}

*抗 D産生細胞樹立 3 株：DBC-5, DBC-11, DBF-11

\section{3. 大量培養打よび産生物の回収}

Bio-ProのファイバーにDBF-11細胞を接種 後, 初回の培地交換は, 12 日目で 1 回の培地量 2.8 リットル必要とし, 以後 131 日間で 85 回総培地量 238 リットル使用した。

抗 $\mathrm{D}$ 抗体価の上昇は, 細胞接種後 3 日目から 5,120 倍, 4 日目から 12 日目が 10,240 倍, 13 日目 20,480 倍, 34 日目から 40,960 倍, 52 日目から $8.2 \times$ 
$10^{4}$ 倍に上昇し，56日目から培地に添加する FBS 量を $5 \%$, 70日目から $3 \%$ に減少したが131日目ま でに約 $8 \times 10^{4}$ 倍の抗体価を維持した（図 2 ）.

産生物の回収量は, 12 日目から 1 日 1 回（休日 を除く) 80 ～90ml の採取量で101回採取し, 総採取 量8.17リットル，ヒト IgG 量は，5.1gであった。 （ラナプレート IgG-L キットで定量）

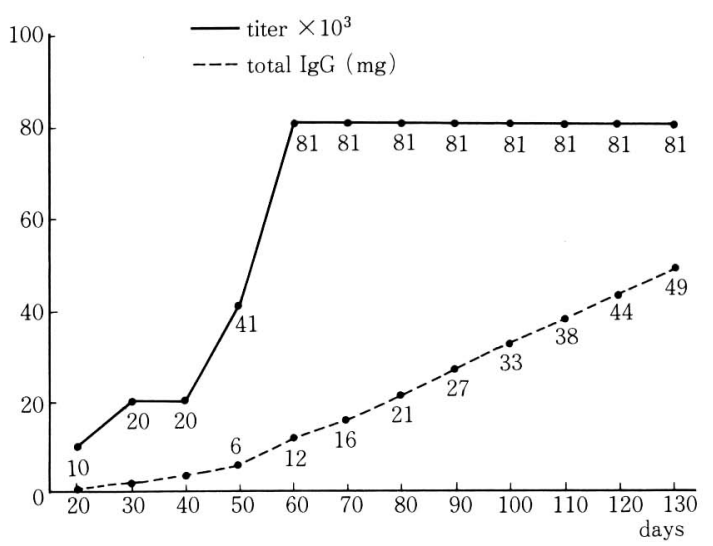

図 2 Bio-Proによる抗 Dモノクローナル抗体の産 生 (DBF-11細胞)

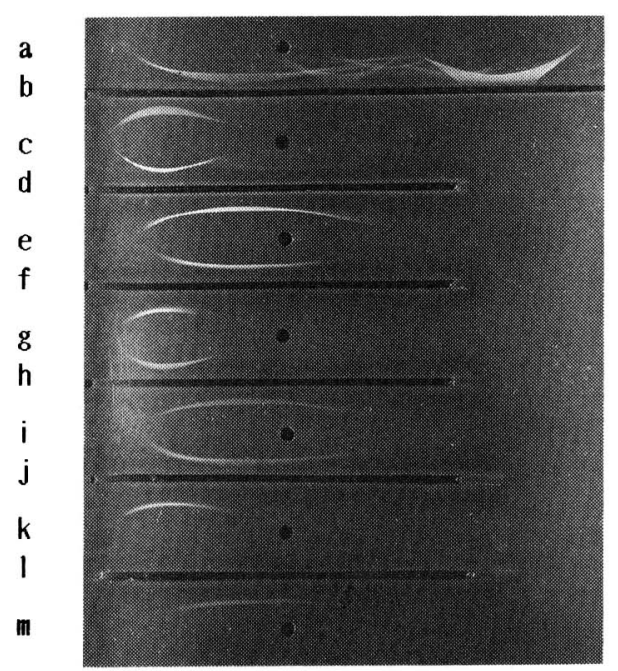

図 3 抗 Dモノクローナル抗体 (DBF-11)の免疫電気 泳動像

a, e, i, m: 正常ヒト血清, b : 抗ヒトウサギ血清, c, g, k : 抗 D モノクローナル抗体 (DBF-11), d : 抗ヒト IgGウサギ血清, $\mathrm{f}$ : 抗ヒト Fab (IgG) ヤギ 血清, $\mathrm{h}$ : 抗ヒト Fc (IgG)ヤギ血清, $\mathrm{j}$ : 抗ヒト $\boldsymbol{~}$ ウ サギ血清, 1 : 抗ヒト $\lambda$ ウサギ血清

\section{4. 産生物の精製および性状}

産生物8.17リットルをホローファイバーで800 $\mathrm{m} l$ に濃縮精製し，ヒト IgG 量は， $4.4 \mathrm{~g}$ であった。

性状は, 免疫電気泳動法により, 図 3 に示すご とく，抗ヒトウサギ血清 (DAKO 製) との反応は, $\operatorname{IgG}$ の位置に沈降線を認め, 抗ヒト IgGウサギ血 清（MILES-YEDA 製）も同様なパターンを認め た。

抗ヒト Fab (IgG) ヤギ血清 (MILES-YEDA 製), 抗ヒト Fc (IgG) ヤギ血清 (MILES-YEDA 製), に対しても特異な沈降線が認められた。抗ヒ ト $\varkappa ＼lambda$ ウサギ血清 (MILES-YEDA 製)に対して は, $\varkappa$ みに沈降線を認め, 入には認めなかった。 免疫グロブリン $(\mathrm{IgG})$ のサブクラは, 表 5 に示 したごとく, IgG subclass specific antisera （M1174 Janssen 社）を用いて，精製抗 Dモノク ローナル抗体感作血球に対し, 抗 IgG1のみ抗グロ ブリン試験が陽性であった。

抗 D の活性は, 表 6 に示すごとく, ブロメリン 法で $4 \times 10^{5}$ 倍, 間接抗グロブリン試験で $8 \times 10^{5}$ 倍あった。

5) 抗 Dモノクローナル抗体 IgGの Fc 部分の 架橋

精製した抗 Dモノクローナル抗体 IgGの Fc 部分を抗ヒト IgG Fc 特異マウスモノクローナル 抗体で架橋した20種類の凝集価, 凝集力試験成績 を表 7 に示した.

食塩液凝集試験では, 抗 Dモノクローナル抗体 量が $40 \mu \mathrm{g} / \mathrm{m} l$ 以上の場合に凝集価が 32 倍以上, 20 $\mu \mathrm{g} / \mathrm{m} l$ では， 8 倍以下であった. 抗ヒト IgGモノ クローナル抗体量 $1.0 \mathrm{~m} l$ の場合は, 凝集価が32倍 であったが $0.5 \mathrm{~m} l$ 以下では，ほとんど16倍以下で あった，凝集の強さが 4 プラスを示したのは抗 D モノクローナル抗体 $60 \mu \mathrm{g} / \mathrm{m} l$ に対し抗ヒト IgG

表 5 抗Dモノクローナル抗体 (IgG) サブクラス

\begin{tabular}{c|c|c|c|c|c|c}
\hline \multicolumn{2}{c}{} & \multicolumn{5}{c}{ Rabbit Anti-human } \\
\cline { 4 - 7 } \multicolumn{2}{c}{} & \multicolumn{2}{c}{ IgG1 } & IgG2 & IgG3 & IgG4 \\
\hline \multirow{2}{*}{$\begin{array}{c}\text { Antigiobulin } \\
\text { Test }\end{array}$} & $\begin{array}{c}\text { Monoclonal } \\
\text { Anti-D } \\
(\mathrm{DBF}-11) \\
\text { AB Serum }\end{array}$ & $\begin{array}{c}\text { Red Cells } \\
\left(\mathrm{R}_{1} \mathrm{R}_{1}\right)\end{array}$ & m & - & - & - \\
\hline
\end{tabular}


表 6 精製抗 $\mathrm{D}$ モノクローナル抗体の力価

\begin{tabular}{c|ccccccccccccccc}
\hline & \multicolumn{11}{c}{} & \multicolumn{11}{c}{ Monoclonal Anti-D(DBF-11) $\times 100$} \\
\cline { 2 - 14 } & $\left(2^{\mathrm{n}}\right)$ & 1 & 2 & 3 & 4 & 5 & 6 & 7 & 8 & 9 & 10 & 11 & 12 & 13 & 14 \\
\hline $\begin{array}{c}\text { Bromelin } \\
\left(\mathrm{R}_{1} \mathrm{R}_{1} 2 \% \text { Cells }\right)\end{array}$ & & 4 & 4 & 4 & 4 & 4 & 3 & 3 & 3 & 2 & 2 & 1 & - & - & - \\
\hline $\begin{array}{c}\text { Antiglobulin Test } \\
\left(\mathrm{R}_{1} \mathrm{R}_{1} \text { 2\% Cells) }\right.\end{array}$ & & 4 & 4 & 4 & 4 & 4 & 4 & 3 & 3 & 3 & 2 & 2 & 1 & 1 & - \\
\hline
\end{tabular}

表 7 抗 $\mathrm{D}$ モノクローナル抗体 $\lg \mathrm{G}$ の $\mathrm{Fc}$ 部の架橋

\begin{tabular}{|c|c|c|c|c|c|c|c|c|c|c|}
\hline \multicolumn{11}{|c|}{ Reactions of Anti-D(DBF-11) by Tube Test $\left[2 \mathrm{~V} / \mathrm{V} \%\right.$ Red Cell $\left(\mathrm{R}_{1} \mathrm{R}_{1}\right)$ Suspensions in Saline] } \\
\hline & \multicolumn{10}{|c|}{ Monoclonal Anti-D(DBF-11) } \\
\hline & \multicolumn{2}{|c|}{$100 \mu \mathrm{g} / \mathrm{ml} \cdot 100 \mathrm{ml}$} & \multicolumn{2}{|c|}{$80 \mu \mathrm{g} / \mathrm{ml} \cdot 100 \mathrm{ml}$} & \multicolumn{2}{|c|}{$60 \mu \mathrm{g} / \mathrm{ml} \cdot 100 \mathrm{ml}$} & \multicolumn{2}{|c|}{$40 \mu \mathrm{g} / \mathrm{ml} \cdot 100 \mathrm{ml}$} & \multicolumn{2}{|c|}{$20 \mu \mathrm{g} / \mathrm{ml} \cdot 100 \mathrm{ml}$} \\
\hline $\begin{array}{l}\text { specitic } \\
\text { Antibody } \\
\text { (mouse) } \\
3.2 \mathrm{mg} / \mathrm{ml}\end{array}$ & Avidity & Titer & Avidity & Titer & Avidity & Titer & Avidity & Titer & Avidity & Titer \\
\hline $1.0 \mathrm{ml}$ & 3 & 32 & 3 & 32 & 4 & 32 & 4 & 64 & 2 & 4 \\
\hline $0.6 \mathrm{ml}$ & 2 & 16 & 3 & 16 & 3 & 16 & 4 & 32 & 3 & 8 \\
\hline $0.25 \mathrm{ml}$ & 2 & 8 & 2 & 8 & 3 & 16 & 3 & 16 & 3 & 8 \\
\hline $0.125 \mathrm{ml}$ & 2 & 8 & 2 & 8 & 3 & 8 & 3 & 16 & 2 & 8 \\
\hline \multicolumn{11}{|c|}{ Reactions of Anti-D(DBF-11)by Tube Test [2V/V\% Red Cell $\left(R_{1} R_{1}\right)$ Suspensions in $20 \mathrm{~W} / \mathrm{V} \%$ Albumin] } \\
\hline & \multicolumn{10}{|c|}{ Monoclonal Anti-D(DBF-11) } \\
\hline & \multicolumn{2}{|c|}{$100 \mu \mathrm{g} / \mathrm{ml} \cdot 100 \mathrm{ml}$} & \multicolumn{2}{|c|}{$80 \mu \mathrm{g} / \mathrm{ml} \cdot 100 \mathrm{ml}$} & \multicolumn{2}{|c|}{$60 \mu \mathrm{g} / \mathrm{ml} \cdot 100 \mathrm{ml}$} & \multicolumn{2}{|c|}{$40 \mu \mathrm{g} / \mathrm{ml} \cdot 100 \mathrm{ml}$} & \multicolumn{2}{|c|}{$20 \mu \mathrm{g} / \mathrm{ml} \cdot 100 \mathrm{ml}$} \\
\hline $\begin{array}{l}\text { Fc Mono- } \\
\text { specific } \\
\text { Antibody } \\
\text { (mouse) } \\
3.2 \mathrm{mg} / \mathrm{ml}\end{array}$ & Avidity & Titer & Avidity & Titer & Avidity & Titer & Avidity & Titer & Avidity & Titer \\
\hline $1.0 \mathrm{ml}$ & 3 & 512 & 3 & 1024 & 3 & 1024 & 4 & 512 & 3 & 128 \\
\hline $0.5 \mathrm{ml}$ & 2 & 512 & 3 & 1024 & 3 & 512 & 4 & 512 & 3 & 256 \\
\hline $0.25 \mathrm{ml}$ & 2 & 512 & 3 & 512 & 3 & 512 & 3 & 512 & 3 & 128 \\
\hline $0.125 \mathrm{ml}$ & 2 & 512 & 3 & 512 & 3 & 512 & 3 & 512 & 8 & 128 \\
\hline
\end{tabular}

Reactions of Anti-D(DBF-11) by Slide Test $\left[40 \mathrm{~V} / \mathrm{V} \%\right.$ Red Cell $\left(\mathrm{R}_{1} \mathrm{R}_{1}\right)$ Suspenions in $6 \sim 8 \mathrm{~W} / \mathrm{V} \%$ Albumin and Saline]

\begin{tabular}{|c|c|c|c|c|c|c|c|c|c|c|}
\hline \multirow{3}{*}{ 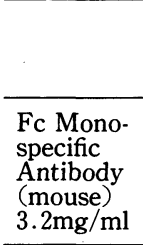 } & \multicolumn{10}{|c|}{ Monoclonal Anti-D(DBF-11) } \\
\hline & \multicolumn{2}{|c|}{$100 \mu \mathrm{g} / \mathrm{ml} \cdot 100 \mathrm{ml}$} & \multicolumn{2}{|c|}{$80 \mu \mathrm{g} / \mathrm{ml} \cdot 100 \mathrm{ml}$} & \multicolumn{2}{|c|}{$60 \mu \mathrm{g} / \mathrm{ml} \cdot 100 \mathrm{ml}$} & \multicolumn{2}{|c|}{$40 \mu \mathrm{g} / \mathrm{ml} \cdot 100 \mathrm{ml}$} & \multicolumn{2}{|c|}{$20 \mu \mathrm{g} / \mathrm{ml} \cdot 100 \mathrm{ml}$} \\
\hline & $\underset{(S)}{\text { Albumin }}$ & $\underset{(S)}{\text { Saline }}$ & $\underset{(\mathrm{S})}{\text { Albumin }}$ & $\begin{array}{l}\text { Saline } \\
(\mathrm{S})\end{array}$ & $\underset{(\mathrm{S})}{\text { Albumin }}$ & $\underset{(\mathrm{S})}{\text { Saline }}$ & $\underset{(\mathrm{S})}{\text { Albumin }}$ & $\begin{array}{c}\text { Saline } \\
(\mathrm{S})\end{array}$ & $\underset{(\mathrm{S})}{\text { Albumin }}$ & $\underset{(\mathrm{S})}{\text { Saline }}$ \\
\hline $1.0 \mathrm{ml}$ & 10 & 9 & 11 & 10 & 10 & 10 & 12 & 11 & 15 & 15 \\
\hline $0.5 \mathrm{ml}$ & 11 & 11 & 11 & 11 & 11 & 11 & 13 & 12 & 13 & 14 \\
\hline $0.25 \mathrm{ml}$ & 12 & 12 & 12 & 12 & 13 & 13 & 14 & 13 & 14 & 14 \\
\hline $0.125 \mathrm{ml}$ & 14 & 14 & 13 & 13 & 13 & 13 & 15 & 14 & 16 & 15 \\
\hline
\end{tabular}

(S) : Second 
モノクローナル抗体 $1.0 \mathrm{~m} l$ の場合および抗 D モ ノクローナル抗体 $40 \mu \mathrm{g} / \mathrm{m} l$ に対し抗ヒト IgGモ ノクローナル抗体 $1.0 \mathrm{~m} l, 0.5 \mathrm{~m} l$ の場合計 3 種で あった。

アルブミン凝集試験では。抗 D モノクローナル 抗体 $20 \mu \mathrm{g} / \mathrm{m} l$ の場合を除き他は凝集価が512倍以 上であった.

凝集の強さは抗 Dモノクローナル抗体 $40 \mu \mathrm{g} /$ $\mathrm{m} l$ の場合 4 プラスであった.

凝集開始時間は，抗 D モノクローナル抗体及び 抗ヒト IgGのいずれの濃度も高い場合に $9 \sim 12$ 秒と速く, いずれの濃度も低い場合は $13 \sim 16$ 秒と 遅くなった。

\section{IV. 考 察}

安定な抗 D ノクローナル抗体産生株の樹立 は，抗 D 産生 EBV トランスフォーム B2-1細胞と JMS-3細胞の融合，いわゆる“EBV-ハイブリドー マ法”を用いた。

融合効率は, 1well 当りの植え込み細胞数 $1 \times$ $10^{5}$ 個の場合と $5 \times 10^{4}$ 個の場合，それぞれ $23 / 30$ well (76.7\%)，21/36well (58.3\%)であり，両者 間に有意な差は認めなかった。

各クローンには，それぞれ23/23well (100\%)， 21/21well (100\%) のすべてに抗 D の産生を認め た。

単クローン化は, 各クローンのらち抗 D 抗体価 の高い6well (B-7, B-11，D-7，D-11，B-8，D-5) の細胞について，各々クローニングを行なったと ころ，総数 537 well 中521well (97.0\%) に増殖を 認め, このうち374well (66.6\%) に抗 D の活性を 認めた。

D-5細胞のクローニングによって分離した 65 well 中の単クローンの中で抗 D 活性の高い B-9 細胞を再クローニングし, B-11, C-11, E-8, B-5, $\mathrm{B}-8, \mathrm{E}-2$ の 6 種の細胞株を分離し，そのうち B-11 細胞の再クローニングによって DBC-5, DBC-11, DBF-11の 3 種の細胞株を分離した。

これらの細胞株のうち DBF-11細胞株（培養上 清：抗 D 抗体価 1,280 倍, ヒト IgG 量 $40 \mu \mathrm{g} / \mathrm{m} l$ ) を抗 D モノクローナル抗体産生細胞として確立 した.
Bio-Proによる大量の連続培養は, 機械に装着 したヴィタファイバーVに VBF-11細胞を $2 \times$ $10^{8}$ 個接種して10\%FBS 加 RPMI1640倍地を循環 させ, 細胞注入日から，12日目（抗 D 抗体価が 10,240倍）に生成物の最初の回収を行った。

培地中の FBS 濃度を初期の $10 \%$ から, 抗 D 抗 体価の上昇（細胞の増殖）に伴って $5 \%$ に减じ, 細胞の増殖がプラトーに達した時点で $3 \%$ に減じ ても抗 D 抗体価がブロメリン法で 4 万〜 8 万を 維持した。

131日間の培養で生成物の総回収量は, $8.17 リ ッ$ トル，その抗 D 抗体価は 4 万，ヒト IgG 量として $5.1 \mathrm{~g}$ 回収できた。

図 4 は, 24well マイクロプレートでDBF-11細 胞を 7 日間培養の細胞増殖曲線を示している。培 養後 4 日目には，培養上清中の抗 D抗体価が 1,280 倍, ヒト $\mathrm{IgG}$ 量として $40 \mu \mathrm{g} / \mathrm{m} l$ の産生を認 め, 今回 Bio-Proに使用した総培地量 238 ット ルから産生するヒト IgG 量は, 計算上の回収可能 なヒト IgG 量は, $9.52 \mathrm{~g}\left(40 \mu \mathrm{g} / \times 2.38 \times 10^{5} \times\right.$ $\left.10^{-6}\right)$ と推定されることから，回収率は $53.6 \%$ （5.1/9.52g）と低值であった。

ヴィタファイバーから濾出して循環培地中に移 行した産生物を $40 \%$ 飽和硫酸アンモニウムで塩析 し，ヒト IgG 量として約 $2.8 \mathrm{~g}$ 回収できた。した がって, ヴィタファイバー中で産生した総 IgG 量 は, 約 $7.9 \mathrm{~g}$ となり, 推定值 $9.52 \mathrm{~g}$ の約 $83 \% か ゙$ 産生

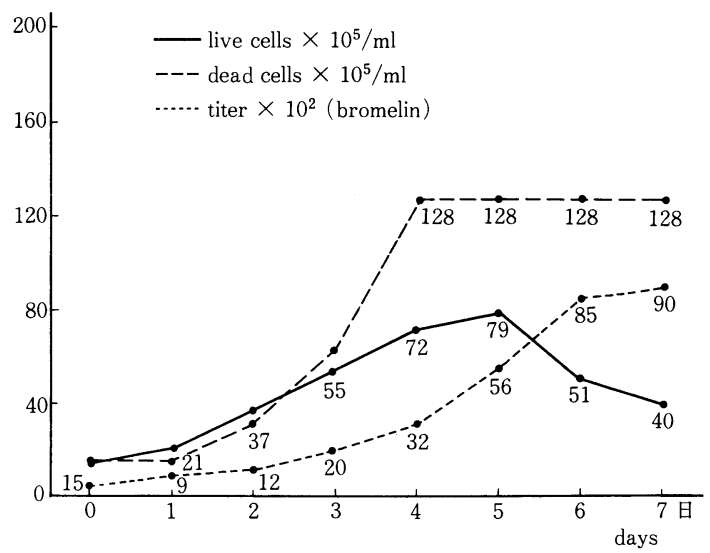

図 4 24well マイクロプレートによる培養（DBF-11 細胞） 
したことになる，精製過程の塩析による消失分を 加算すると実際には，8.7～9.0g 産生したことに なり，循環培地の FBS 量を通常の培養条件(10\% FBS 添加) に比して約 $1 / 3$ 量 (3\%) に减じても抗 $\mathrm{D}$ モノクローナル抗体の産生量が多く, ヴィタ ファイバー表面に打ける栄養素の交換が効率良く 行われていることが確認できた。

この方法によれば，融合細胞 (DBF-11) から産 生する抗 D ノクローナル抗体 (IgG) 量は, 培地 $1 \mathrm{~m} l$ 当り $37 \sim 38 \mu \mathrm{g}$ であり, 別の実験によると図 4 に示すごとくマイクロプレートによる培養で は， 5 日目の培養上清中の $\operatorname{IgG}$ 量が $40 \mu \mathrm{g} / \mathrm{m} l$ で あることと比較して, IgG 産生量に殆ど差が認め られなかった。

欠点は，ヴィタファイバーから循環培養液中に 産生物が濾出することであり，これを改善する為 にヴィタファイバーの分画分子量の平均ポアサ イズ30,000を20,000のサイズに小さくすればある 程度回収率が改善されると考えられるが細胞増殖 に要する栄養素等の補給, 代謝産物の除去等の効 率について今後検討をする必要がある.

産生物8.17リットル（ヒト IgG 量5.1g）の精製 は, ホローファイバーを用いた限外濾過で $800 \mathrm{~m} l$ に精製濃縮し，ヒト IgG 量として $4.4 \mathrm{~g}$ 回収した。
回収率は $86.3 \%$ であった。

免疫グロブリンの性状は，免疫電気泳動法に よって, IgG， $\varkappa$ 型 (L 鎖)であり，サブクラスは 凝集反応によって IgG1と判定した。

抗 D 活性は, ブロメリン法で $4 \times 10^{5}$ 倍, 間接抗 グロブリン試験で $8 \times 10^{5}$ 倍であった. 諸外国で市 販されている血液型判定用抗 D モノクローナル 抗体は, 免疫グロブリンクラスで分類すると IgG， $\operatorname{IgM}$ タイプの 2 種であり, 前者はアルブミン液 法，後者は生理食塩液法と用法が異なっている。

我々の確立した細胞 (DBF-11) が産生する抗 D モノクローナル抗体も IgG タイプであり，外国で 使用されているアルブミン液法用に該当するが, 各種の検查法に使用可能な血液型判定用試薬とす るため, 精製抗 D モノクローナル抗体（ヒト IgG） $40 \mu \mathrm{g} / \mathrm{m} l$ に対し, 抗ヒト IgG (Fc 特異) マウスモ ノクローナル抗体（マウス IgG） $32 \mu \mathrm{g} / \mathrm{m} l$ の混合 比で抗 Dモノクロ一ナル抗体 $\mathrm{IgG}$ の Fc 部を架 橋することによって凝集反応系の諸条件（生理食 塩液法, アルブミン液法, 蛋白分解酵素法, 抗グ ロブリン法) のいずれの方法を用いても Rho (D) 血液型の判定を可能とし, 同時に感度も上昇した。

この抗 D 血液型判定用モノクローナル抗体〔商 品名：抗 D「日赤」, 施設記号：OSK3〕の特異性

表 8 抗 D抗体を保有する Pho（D）陽性血球に対する反応

\begin{tabular}{|c|c|c|c|c|c|c|c|c|c|c|c|c|c|c|}
\hline \multirow{3}{*}{$\begin{array}{c}\text { Red Blood Cells } \\
\text { of Category }\end{array}$} & \multicolumn{12}{|c|}{$\begin{array}{l}\text { Reactions of Anti-D Made by People } \\
\text { with Red Cells of Category }\end{array}$} & \multicolumn{2}{|c|}{$\begin{array}{l}\text { Monoclonal } \\
\text { Anti-D(DBF-11, } \\
\text { OSK3) }\end{array}$} \\
\hline & \multirow[t]{2}{*}{ II } & \multicolumn{3}{|c|}{ III } & \multicolumn{3}{|c|}{ IV } & \multicolumn{3}{|c|}{ V } & \multicolumn{2}{|c|}{ VI } & \multirow[b]{2}{*}{$\mathrm{S}$} & \multirow[b]{2}{*}{$\mathrm{P}$} \\
\hline & & $a$ & b & $c$ & $a$ & $a$ & $\mathrm{~b}$ & $a$ & $\mathrm{~b}$ & c & $\mathrm{i}$ & ii & & \\
\hline II & - & + & + & + & + & + & w & + & + & $\mathbf{w}$ & + & + & nt & nt \\
\hline III a & + & - & + & - & + & + & + & + & + & + & + & + & + & + \\
\hline $\mathrm{b}$ & + & - & - & - & + & + & + & w & + & + & + & + & $\mathrm{nt}$ & $\mathrm{nt}$ \\
\hline$c$ & + & - & + & - & + & + & + & + & + & + & + & + & $+w$ & $+w$ \\
\hline IV a & - & $\mathbf{w}$ & + & - & - & - & - & + & + & - & + & + & + & + \\
\hline $\mathrm{b}$ & - & w & + & $\mathrm{w}$ & - & - & - & - & + & $\mathbf{w}$ & + & - & w & + \\
\hline $\mathrm{V}$ a & + & - & + & - & + & w & + & - & w & - & + & - & $-/+$ & + \\
\hline b & + & - & + & - & + & - & - & - & - & - & - & - & nt & nt \\
\hline$c$ & + & - & + & - & w & - & $\mathbf{w}$ & - & - & - & + & - & nt & nt \\
\hline VI & - & - & + & - & + & - & + & - & - & - & - & - & - & - \\
\hline Rh33 & & & & & & & & & & & & & - & - \\
\hline
\end{tabular}

S : Agglutination of Cells in Saline Suspension

（文献14）

P : Agglutination of Papain-treated Cells 
については, 著者らが献血者603例に対する試験で 確認している ${ }^{8}$.

臨床検查用試薬としては, 十字ら ${ }^{9)}$, 中田ら ${ }^{10)}$, 田村ら ${ }^{11)}$, 大久保ら ${ }^{12)}$ にっって特異性, 凝集力, 相 関性等について良い評価を得ており，臨床検査に 十分使用できることが確認できた。

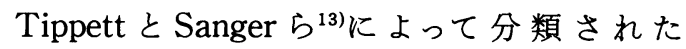
Rho (D) 陽性でかつ抗 D 抗体をもつ赤血球 (カテ ゴリーII〜VI）に対する反応性については，英国 MRCの Dr. Tippett に確認を依頼し, その試験結 果を表 $8^{14)}$ に示した.カラゴリーIII, IV，Vには凝 集し, VIには凝集せず, Rh33にも凝集しなかった。

一方, Lowe ら ${ }^{4)}$ の作製した抗 Dモノクローナ ル抗体（HD7）は, III, V, VIに凝集し, IVに凝 集せず, Rh33にも凝集しなかったと報告し, Paire

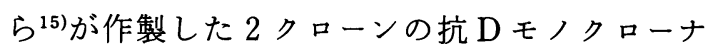
ル抗体は, 1 クローン Coll 8.8がIII, IV, V, VI のすべてに凝集し，もう一つのクローン Coll 7.12 は, IIIのみに凝集し, IV, V, VIに凝集せず, Rh33 とは2クローンとも凝集しなかったと報告してい る.

我々の作製した抗 D 血液型判定用モノクロー ナル抗体 (DBF-11) は, Rho (D) variantに対す る反応性が Lowe ら (HD7), Paire ら (Coll 8.8, Coll 7.12) が報告した抗 Dモノクローナル抗体と 一部異なることが分かった。

これら種々の抗 Dモノクローナル抗体は, 今後 の Rho (D) 抗原の variant を分類する上で有用で あると考えられる。

今回, 我々は各種の検查方法を用いて Rho (D) 血液型の判定が可能な抗 D 血液型判定用モノク ローナル抗体の開発に国内で初めて成功した。

$$
\text { 文献 }
$$

1) Koskimies, S.: Human lymphoblastoid cell line producing specific antibody against $\mathrm{Rh}$ antigen D. Scand. J. Immunol., 11 : 73-77, 1980.

2) Boylston, A.W., et al.: Production of human IgM anti-D in tissue culture by EB-virustransformed lymphocytes. Scand. J. Immunol., $12: 355-358,1980$.

3) Bron, D., et al.: Production of human monoclonal IgG antibodies against Rhesus (D) antigen. Proc. Natl. Acad. Sci. U.S.A., 81 : 3214 $-3217,1984$.

4) Lowe, A.D., et al.: A human-human monoclonal anti-D by direct fusion with a lymphoblastoid line. Vox Sang., $51: 212-216,1986$.

5）宇野成恒, 他：単クローン性抗 Rh (D) 抗体を産 生するヒト細胞株の樹立. 第13回日本免疫学会総 会記録, 416-417, 1983.

6）高橋英夫, 他：細胞融合による単クローン性ヒ卜 抗 $\mathrm{Rh}_{0}(\mathrm{D})$ 抗体の産生について. 日輸血会誌， 32 : 253, 1986.

7) 星野真由美, 他: 単クローン性ヒト抗 $\mathrm{Rh}_{\mathrm{o}}$ (D) 抗 体の血清学的検討について. 日輸血会誌, $32: 253$, 1986.

8）山野孟, 他：抗 D 血液型判定用モノクローナル 抗体の評価. 機器・試薬, 11(3) : 370-371, 1988.

9）十宇猛夫, 堀江登志子：抗 D 血液型判定用モノク ローナル抗体の評価. 機器·試薬, 11(3) : 355-357, 1988.

10）中田弘, 大河内一雄：抗 D 血液型判定用モノク ローナル抗体の評価. 機器・試薬, 11(3) : 358-361, 1988.

11）田村 葚, 他：抗 D 血液型判定用モノクローナル 抗体の評価. 機器・試薬, $11(3)$ : 362-366, 1988.

12）大久保進, 他：抗 D 血液型判定用モノクローナル 抗体の評価. 機器・試薬, 11(3) : 368-369, 1988.

13) Tippett, P. and Sanger, R.: Observations on subdivisions of the Rh antigen D. Vox. Sang., $7: 9-13,1962$.

14) Tippett, P.: 私信.

15) Paire, J., et al.: Establishment of human cell lines producing anti-D monoclonal antibodies: Identification of rhesus D antigen. Immunology Letters, 13 : 137-141, 1986. 